\title{
Knowledge Spirals in Higher Education Teaching Innovation
}

\section{Ángel Fidalgo-Blanco}

Laboratory of Innovation in Information Technologies. LITI. Technical University of Madrid. Calle de Ríos Rosas, 21, 28003 Madrid, Spain

E-mail: angel.fidalgo@upm.es

\section{María Luisa Sein-Echaluce}

Department of Applied Mathematics, University of Zaragoza, Campus Rio Ebro, María de Luna 3, 50018 Zaragoza, Spain

E-mail: mlsein@unizar.es

\section{Francisco J. García-Peñalvo}

Computer Science Department, Research Institute for Educational Sciences, GRIAL research group, University of Salamanca, Faculty of Science - Plaza de los Caídos S/N. 37008 Salamanca, Spain E-mail: fgarcia@usal.es

\begin{abstract}
A R\&I\&i process for a knowledge management system development is presented. It transforms different institutions experiences into organisational knowledge applicable to an entire sector, the higher education one specifically. The knowledge management system allows classifying, organising, distributing and facilitating the application of the knowledge generated by the faculty. A study, with more than 1000 system users, reflects that the system helps to the faculty in the way they perform educational innovation activities. The supported model integrates both Nonaka's epistemological and ontological spirals. This allows defining ontologies and used them in order to transform the individual knowledge into organisational one. The knowledge management system encapsulates complex logic expressions and ontologies management, making easy for the users obtaining surccessful results that may organise in their own way, becoming a powerful knowledge managementprocess that combines epistemological and ontological knowledge spirals to convert individual experiences in educational innovation into organisational knowledge in the higher education sector.
\end{abstract}

Keywords: Knowledge management System, Ontologies, Knowledge Spirals, Educational Innovation, Higher Education

\section{INTRODUCTION}

All societies are symbolized by resources. In agriculture, the grain is a symbol of its activity, the industry itself in the industrial sector, and the knowledge in the current society. For centuries it has been considered that knowledge contributes value to people, but it is the knowledge society that considers that it contributes value to organisations (Sánchez and Elena, 2006) thus making them more competitive (Van den Hooff and De Ridder, 2004; Yang, 2007).However, that contributes value to organisations should be managed, then knowledge management is born with the aim to improve competitiveness. The first experiences in knowledge management came about in private companies (Whitworth, 2012). Currently, most industries use knowledge management to achieve competitive advantages (Tan et al., 2007; Wu et al., 2011). 
Knowledge management is based on collecting, organising, distributing, sharing and using the intellectual assets of an organisation (persons, knowledge resources and relationship) and should benefit its members (Tseng and Kuo, 2014). Therefore, an activity centred on knowledge implies the exchange of knowledge between organisation members (Bartol and Srivastava, 2002; Koulikov, 2011) and this exchange can contribute to the application of knowledge and the innovation (Sheng and Noe, 2010). In addition, innovation in organisations is closely linked to knowledge management (Nonaka 1991; Nonaka and Takeuchi, 1995; Davila et al., 2006) and both improve competitiveness (Al-Husseini and Elbeltagi, 2015).

On the other hand, higher education is also in a competitive context (students and funding) (Roffe, 1998), so it incorporates knowledge management in order to improve the quality of their services (Weatherly, 2003). Due to all of the foregoing, higher education has the same global challenges as the companies, because it is also in a changing context (Al-Husseini and Elbeltagi, 2015).

The innovation, knowledge sharing and knowledge itself are factors considered in higher education, like in the industry, to improve the quality, to adapt, evolve and compete. Innovation and exchange of good practices (Roffe, 1998) are the means used by universities for the continual improvement of their quality (García-Peñalvo, 2011). Innovation is a strategic option (Child, 1972; Whitworth, 2012) that creates knowledge (Nonaka and Tackeuchi, 1995) and its management is necessary. However, that universities have strategic plans to encourage innovative practices, it does not mean that innovation occurs. Knowledge management mechanisms are necessary, such as spaces where innovation practices can be located (Gunn, 2010), replicated and applied in the own learning. Transferring knowledge from experts to novices (Hinds et al., 2001), sharing the most relevant information and using resources more efficiently, are all essential objectives (Davenport and Prusak, 1998; Damodaran and Olphert, 2000). Therefore, it is necessary to manage the Educational Innovation (hereinafter EI) and that management should be based on exchange processes of good practices (Koulikov, 2011).

The capability to identify and access the knowledge created in different units of the organisation has significant benefits to improve the performance (Hansen, 2002; Boh, 2014). Consequently, teacher performance improves and it produces more effective work of teachers with students (Cochran-Smith and Lytle, 1999; Kao and Tsai, 2009;MCLaughlin, 2002). The EI is a tool that helps universities to adapt to new demands, new competitive forms, new business models and most importantly, to reduce academic failure rates and improve learning results. It is eommon that universities use the ICT to share knowledge about EI in a virtual way (Alavi and Leidner, 2001) through institutional repositories (Gray and Meister, 2004; Ma and Agarwal, 2007; Boh, 2014). -This leads to the cost of the knowledge search, the difficulty to find relevant information in those repositories (Schultze and Vandenbosch, 1998; Gray and Durcikova, 2005; Huang et al., 2007; García-Peñalvo, 2015). This cost is very high when the repositories are not designed to enable the knowledge reuse (Huber, 2001; Markus, 2001), one of the main problems of the knowledge transfer. If good practices have not been created to be shared, then the cost of the search is excessive and the repositories become completely ineffective (Fidalgo and Ponce, 2011). The main objective of this study is to convert the knowledge derived from the EI experiences (produced by teaching staff in higher education) into sectorial knowledge applicable to the whole sector of higher education. To do so, a methodology is proposed, that increases the effectiveness of a knowledge repository to organise and manage EI good practices and its efficiency in searches, which favours the exchange of knowledge. The difficulties that need to be overcome and are characteristics of higher education are shown in the next section. Then the theoretical model of the repository and its performance under different approaches are defined. The research methodology followed in this work is described. The results of applying this methodology are analysed, followed by the discussion and conclusions. 


\section{CONTEXT}

Nonaka and Takeuchi (1995) consider two types of organisations, depending on their ability to create innovation: bureaucratic organisations in which it is difficult to naturally create the innovation and creative force organisations in which innovation is easily created but its management is difficult, due to its variety and disparity. From the point of view of the EI, the University is an organisation of creative force. Innovation is created in micro-contexts (subjects) and comes about from specific objectives. All of this makes difficult to produce unified innovation theories (Whitworth, 2012). In this way, the problem of obtaining a unified view of the EI experiences of the different teaching staff is evident. This makes the management of this type of knowledge difficult in a repository. The EI experiences usually arise as an answer to specific needs of the subjects. Therefore, what is innovative for a subject might not be innovative for another subject (Veletsianos, 2010). Teaching staff cares to solve specific problems associated to their own subjects and the initial design of their specific experiences does not provide information that is to be transferred and reused. This situation requires a large effort in conducting searches (Schultze and Vandenbosch, 1998); it is called cognitive processing. The second problem to manage EI is related to the low efficiency of the search engines associated to the repositories. This is because the EI experiences only provide information for specific subjects, where they have been applied. This leads to an excessively time consuming process in order to identify the useful information. Hence, Whitworth (2012) recommends basing the organisation's repositories on uniformity. Other papers suggest not making repositories that involve people from different working environments and contexts ( $\mathrm{Su}$ and Contractor, 2011; Hansen and Haas, 2001). Other problems are identified regarding the organisational and individual culture. The organisation should promote exchange to enable the sharing of EI experiences. However, individuals often have no culture of sharing or receiving (this is associated to the lack of knowledge). Therefore, there are obstacles to convert knowledge, provided individually, in organisational and sectorial knowledge. This work provides a new way of facing the identified problems and, in some aspects, is contrary to the conclusions of other research works. The research questions considered in this paper are:

1. Is it feasible to carry out centralised repositories that integrate EI good practices from different universities? A single centralised repository, with the EI experiences from various organisations is propossed; in other words, a sectorial approach. Other research says that repositories should be specific, even within the same organisation. The answer to this question will show us whether these previous studies are confirmed or if, on the contrary, a new approach is found that integrates individual, dispersed and specific elements within a common view.

2. Is it possible to easily identify and apply EI experiences arising from different subjects? According to previous research, a great investment in search time is needed to find an EI experience applicable into a different context to own experience. If, for example, a professor of Literature is looking for good practice in Physics, then it requires a great deal of cognitive effort to locate useful innovation and to subsequently apply it. This situation makes the knowledge repository inefficient. This paper shows a way to improve the efficiency of the search engines in these circumstances.

3. Is it possible to build a sectorial knowledge management system for all universities, regardless of the organisational culture of each university? All of the universities promote the attainment of EI, but the management of this innovation is frequently limited to encode and store this practice (Boh, 2014) but a classification, organisation, distribution and application policy are not included. Therefore, universities have not usually a policy for transferring individual knowledge into organisational knowledge. Our approach goes beyond that; it involves having a 
sectorial view (which is greater than an organisational one), regardless of the management actions that each university carries out.

Next, the theoretical model and the creation of ontologies that compose the model are presented.

\section{THEORETICAL MODEL}

The idea of storing EI good practices is not new in universities. In order to store good practice, having a simple website or a generic repository may be enough to store good practices. Nevertheless, this approach lacks in its application into the rest of the organisation to exchange the knowledge.

In this model, the knowledge management and its exchange are based on integrating three aspects:

1. The Nonaka model of knowledge spirals: it defines the processes involved in the creation of organisational and sectorial knowledge from individual and group knowledge. Nonaka (1991) bases his model on the two types of knowledge spirals: the epistemological spiral (interaction between types of knowledge) and the ontological spiral (interaction between knowledge from people and organisations). The first spiral is based on the transformation between tacit and explicit knowledge (Sein-Echaluce et al., 2013). The second spiral is based on phases involved in the conversion of individual knowledge into organizational knowledge and from organisational knowledge that can be used by individuals (Nonaka \& Takeuchi, 1995).

2. Ontologies as a means to classify and visualise the knowledge that is managed (García-Peñalvo et al., 2012). These have been proposed as the definitive solutions to the problems knowledge exchange (Correa da Silva, 2002); they offer types of explicit relationships with very different knowledge elements.

3. Multi-layer knowledge management System. Nonaka (1991) proposes, in a theoretical way, that there should be a layer called hypertext organisation. In this model, and depending on the need, knowledge can be classified from either an organisational, group or individual view. Recent researches consider that this layer can be achieved based on the coexistence of a conceptual view of knowledge (meta-information) and a physical view (data) (Liu et al., 2011).

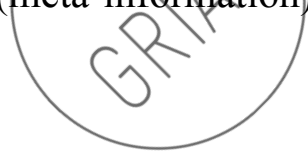


The Figure 1 shows the flow of knowledge included in this work.



Figure 1. Conceptual model

The components of the conceptual model are:

- The epistemological spiral is the continual flow of knowledge that dynamically creates ontologies.

- Ontologies. They are obtained from the epistemological spiral and are used to:

- Classify, categorise and organise the knowledge of the EI practice.

- Allow the transfer $\backslash f$ knowledge from individuals to groups, groups to organisational, organisational to sectorial and sectorial to individual, by means of a continual flow of knowledge (ontotogical spiral).

- Satisfy the objectives of the knowledge management system in terms of enabling the application of the EI.

- The ontological spiral is the continual flow of individual and group knowledge in organisational and sectorial knowledge.

- Knowledge management. It classifies, organises and enables semantic search mechanisms by means of ontologies to disseminate and apply organisational knowledge created in the ontological spiral. The knowledge manager has been carried out using the CSORA method (Fidalgo and Ponce, 2011).

The CSORA method integrates the models referred to at the start of the section and has two main layers: a physical layer in which knowledge is stored, and a conceptual layer that is aimed at the needs of the different users. CSORA uses ontologies to organise and classify knowledge. It also has functions associated with the processes included in the Nonaka's epistemological spiral.

From an ontological spiral produced by more 300 teachers with EI experience, the authors (Sein-Echaluce et al., 2013) obtained the following EI indicators included in Table 1. 
Fidalgo-Blanco, Á., Sein-Echaluce, M. L., \& García-Peñalvo, F. J. (2014). Knowledge Spirals in Higher Education Teaching Innovation. International Journal of Knowledge Management, 10(4), 16-37. doi: 10.4018/ijkm.2014100102

\begin{tabular}{|c|c|c|c|c|}
\hline Characteristics & Motivation & Facilitators & Limitations & Success \\
\hline $\begin{array}{l}\text { Sustainable and } \\
\text { transferable }\end{array}$ & $\begin{array}{l}\text { Official } \\
\text { recognition }\end{array}$ & Institutional support & $\begin{array}{l}\text { Lack of } \\
\text { indicators }\end{array}$ & $\begin{array}{l}\text { Capability to be } \\
\text { reproduced in } \\
\text { other subjects }\end{array}$ \\
\hline $\begin{array}{l}\text { Intentional } \\
\text { change } \\
\text { Monitoring and } \\
\text { evaluation }\end{array}$ & $\begin{array}{l}\text { Monetary } \\
\text { compensation }\end{array}$ & Co-workers & $\begin{array}{l}\text { Lack of } \\
\text { training }\end{array}$ & $\begin{array}{l}\text { Renewal of } \\
\text { methodologies }\end{array}$ \\
\hline $\begin{array}{l}\text { Effectiveness of } \\
\text { results }\end{array}$ & Professionalism & $\begin{array}{l}\text { Cloud technological } \\
\text { resources }\end{array}$ & $\begin{array}{l}\text { Resistance to } \\
\text { change }\end{array}$ & $\begin{array}{l}\text { Effectiveness } \\
\text { Efficiency }\end{array}$ \\
\hline Student activity & $\begin{array}{l}\text { Capture student } \\
\text { interest }\end{array}$ & Student support & & $\begin{array}{l}\text { Active student } \\
\text { participation } \\
\text { Student } \\
\text { motivation } \\
\text { Transversal } \\
\text { competencies }\end{array}$ \\
\hline & $\begin{array}{l}\text { Responsibility } \\
\text { and challenge }\end{array}$ & $\begin{array}{l}\text { Experien } \\
\text { teaching }\end{array}$ & $\begin{array}{l}\text { Effort of } \\
\text { teaching staff }\end{array}$ & $\begin{array}{l}\text { Adaptability to } \\
\text { resources }\end{array}$ \\
\hline & $\begin{array}{l}\text { Cooperation } \\
\text { with other } \\
\text { teaching staff }\end{array}$ & & $\begin{array}{l}\text { Lack of } \\
\text { support } \\
\text { resources }\end{array}$ & \\
\hline & $\begin{array}{l}\text { Continual } \\
\text { improveme }\end{array}$ & & Not assessed & \\
\hline
\end{tabular}

The ontologies, grouped according to context in Table 2, were obtained based on the indicators reflected in the Table 1. These ontol gies are used to classify and organise the EI experiences based on three contexts: learning, innovation creation, and type of practice.

Table 2. EI ontologies grouped by context

\begin{tabular}{|l|l|l|}
\hline \multicolumn{2}{|c|}{ CONTEXT } \\
\hline LEARNING & $\begin{array}{l}\text { CREATING } \\
\text { INNOVATION }\end{array}$ & $\begin{array}{l}\text { TYPE OF PRACTICAL } \\
\text { WORK }\end{array}$ \\
\hline Learning activity & Degree/Qualification & Development \\
\hline Technology & Year & Study \\
\hline Methods and Techniques & Institution & Experience \\
\hline Results & Country & Innovation \\
\hline Generic Competence & Scientific Area & Research \\
\hline & & Type of financing \\
\hline & & Quality level of the practice \\
\hline
\end{tabular}

Each context has a dynamic set of ontologies that vary over time (for example, technology), with the amount of practices (for example institutions) or with the variety of practices (for example in the scientific area). 
How the implemented technological solution works and the points of focus adapted to the individuals and the organisation are presented in the next section..

\section{HOW THE REPOSITORY WORKS}

Applying the CSORA method (Fidalgo and Ponce, 2011) a set of labels is associated to different ontologies from Table 2. By way of example, part of the labels associated with the 'Learning activity" and "Results" ontologies are presented (Table 3 and Table 4, respectively).

Table 3. Labels for the Learning activity ontology

\begin{tabular}{|c|ll|}
\hline ONTOLOGY & \multicolumn{2}{|c|}{ LEARNING ACTIVITY } \\
\hline Associated labels & $\bullet$ & Master class \\
& $\bullet$ & Laboratory class \\
& $\bullet$ & Practical work \\
& • & Evaluation \\
& - & Solving problems and case \\
& & studies \\
& $\bullet$ & Studies \\
& $\bullet$ & Tutoring \\
& $\bullet$ & Subject dynamics \\
\hline
\end{tabular}

Table 4. Labels for the Results ontology

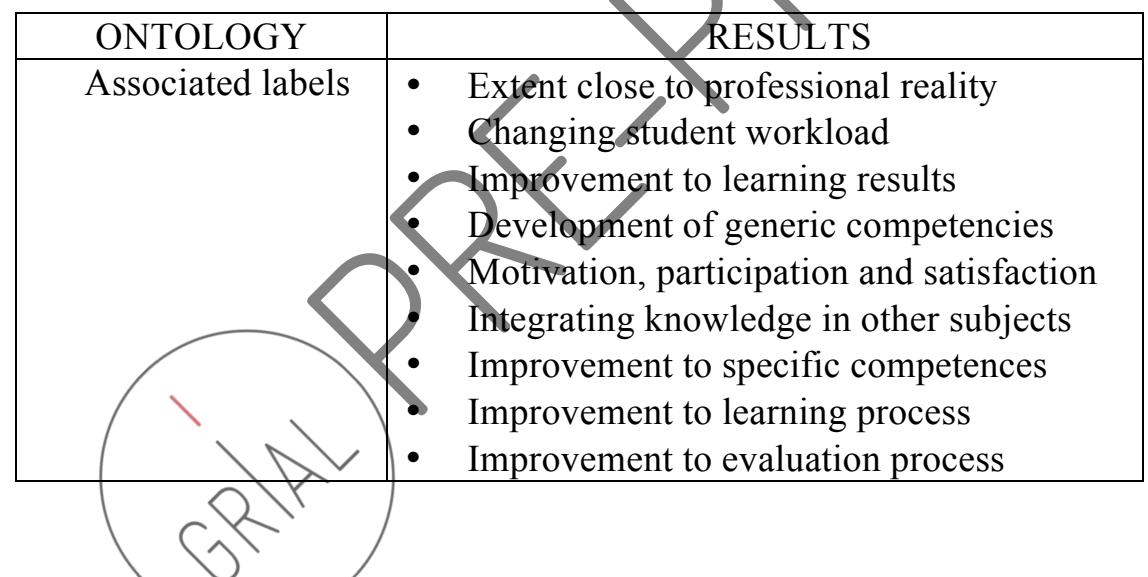

In total 198 labels have been defined, split between 14 ontologies. Next, a brief description of the use of ontologies and labels for the Classification, Searching, Organisation and Relationship processes is offered.

1. Classification. The system assigns any EI experience the group of ontologies and labels that correspond with the characteristics of the experience. The experience is defined in a .PDF file (where the work scientifically structured is described) together with an associated form. Metainformation is associated with the form, consisting of the group of ontologies, labels and their hierarchical relationship. In the Figure 2 the good practice in the left has the following ontologies: Activity (Tutoring and mentoring), Technology (Online platforms) and Methods and Techniques (Autonomous learning). 


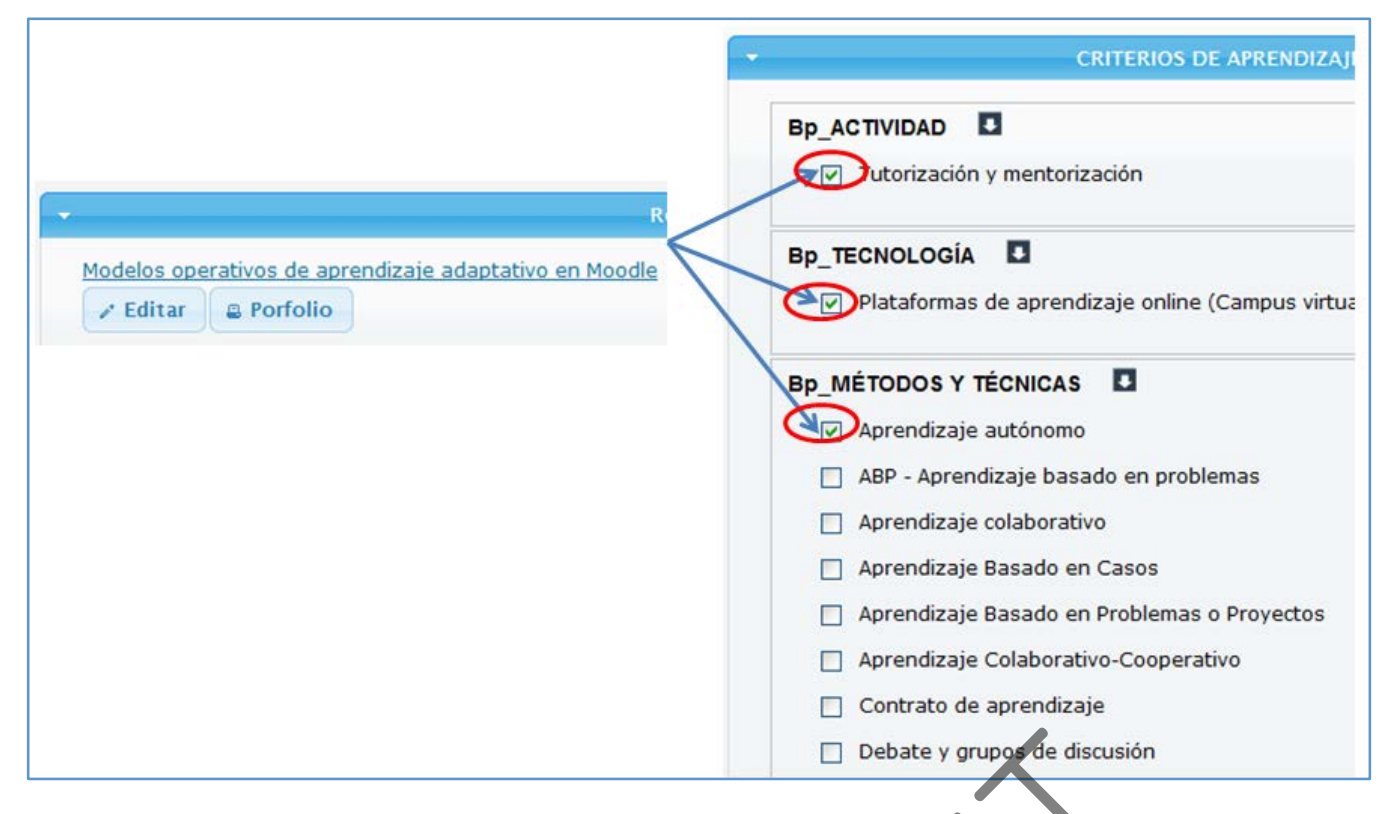

Figure 2. Classification of good practice using ontologies

2. Searching. The search may be by contents (filtered by the different fields of the form), ontologies and labels. For the search to be highly effective, the organisation of Table 2 has been used together with the corresponding labels for each ontology. In this way, the system selects a set of experiences based on:

- Learning: results achieved, techniques used, technologies, competences and learning activities.

- Place and knowledge area: by knowedge area, year, degree or qualification, university and country or region.

- Type of practice and funding: type of innovation, type of funding and quality level of practice.

- Source: this ontology has been added to know the place where the good practice derives from. In this paper the practices have been obtained from different scientific and international EI conferences (Sein-Echaluce et al., 2013).

The innovation presented in this model consists of logical expressions of labels and ontologies being able to be created, allowing a variety of criteria to select good practices. This feature is key to enable the identification of the most useful and suitable knowledge for different situations. It is even effective when the searched knowledge is not previously known, as is seen in Figure 3. 




Figure 3. Semantic search

3. Organisation The search results are normally displayed as lists. When lists have a large number of elements, they are normally paginated; in other words, the organisation of contents is displayed as pages of lists. As the mentioned innovation, the results are organised into sub-lists and each one of them can be paginated. The sub-lists are based on the labels of certain ontologies; that is, for each label a specific list is organised. In our case, the ontology "Type of practical work" has been chosen, which/allows the search results to be organised by: development, study, experience, innovation and investigation. The same experience or practice may have more than one label. Eigure 4 shows an example of the organisation of search results: activity (tutoring and mentoring) and technology (social networks). The final resources are grouped in the type of practice (study, experience and research).



Figure 4. Search results organised into sub-lists

4. Relationship. The EI experiences are varied, so there must be a system that is capable of relating some experiences with others. The system can indicate a set of ontologies to establish the relationship. Once the ontologies for a specific practice have been selected, other practices are displayed that are related with it by means of diverse ontologies.

\subsection{The final product}


The system is sensitive to user's role. With the administrator's role certain tasks can be undertaken such as the loading of data, amendments, etc. The loading system allows experiences to be supplied in an individual way or even from an Excel file.

The most used service of the knowledge management system is the search engine for EI good practice. The conceptual layer provides the system with functions that depend on the users' needs. Sometimes these functions are antagonistic; when this happens it is called dichotomy. The system allows the following dichotomies:

1. Vertical and horizontal focus. The vertical approach is suitable for EI good practice focused on a same type of teaching staff (area of knowledge + subject). The horizontal focus allows the exportation of the EI good practice of different knowledge areas. The searches by labels will be used for the horizontal focus, whilst the searches by content will be used for the vertical focus.

2. Orientation towards the organisation and orientation towards the individual. The initial idea of a knowledge management system is the orientation towards individuals; this service is oriented to teaching staff. Nevertheless, this system can also be used as a service for universities in such a way as if it had been designed for such a purpose.

3. Diversity vs. totality. The dichotomies can be used to integrate two views and give the knowledge management system a much greater scope than expected. Basically, the diversity can be integrated with the totality and both are mutually supportive. Specific and one-off interests of the EI application in the classroom would mark the diversity and the totality would be marked by the classification of these same experienceswith global criteria.

On the other hand, a knowledge management system should serve the individual and the organisation. In our case, the organisation is the sector.

\subsection{Orientation towards the individual}

It is based on the use and efficiency of the proposed application of EI in a day-to-day teaching system. This can be used based on various aspects:

- Learning activities tobe improved or learning activities to which innovation is applied. Activities like: master classes, evaluation, tutoring, etc.

- Technology used to apply the innovation. The system will display practices that have used technology.

- Methods and techniques. Typical ones of the EI like: teamwork, problem based learning, flip teaching, etc.

- Results of learning. A search can be carried out by results or impact on the innovation that is wanted to be obtained; for example, improving the academic performance.

- Generic competence.

- Knowledge area.

- And other more local indicators such as: academic level (year) where the EI is going to be carried out, university, and country.

To do so, the system allows dialling the necessary labels. Therefore, the search should be associated to a maximum number of labels. For example: web 2.0, second year, tutoring, evaluation, student motivation, teamwork and development. In this case, the system offers a way of relating labels by logical expressions. A logical connective "or" is built with the labels of the same ontology and a logical connective "and" is built with the labels of different ontologies. In this example, the logical expression would be: "web 2.0" and 
"second year" and ("tutoring" or "evaluation") and "student motivation" and "teamwork" and "development". In formal language this means that the system searches for knowledge that allows me to apply it to my EI, 2.0 technology, in second year students, for my tutoring or evaluation activities, which are able to motivate students, with the teamwork techniques and the type of knowledge is a development.

The more ontologies and labels that are selected, the greater the possibility that applicable knowledge is identified in a specific and particular situation. Depending on selected ontologies and labels, the search may produce more or less knowledge. In these circumstances, the system allows (with no need to launch a new search) certain labels to be selected or deselected. In such a way, if there are a lot of results in the first search, the selection of more labels produces a greater level of accuracy (the knowledge located will comply with all of the specifications). Conversely, if after a search some of the labels are deselected, then the new search will be more generic and more knowledge will be displayed. In addition, the system allows the classification of good practice with general criteria that are more associated with the innovation itself than with teaching. The system also allows the possibility to create studies either by universities or by sectors.

The most suitable ontologies to carry out this type of search are: Type of financing, type of practice, and quality of EI.

All of the foregoing allows making studies by universities. By selecting the name of a university and a label, all of the knowledge can be analysed for a specific university that uses, for example, 2.0 web technology. By only selecting one label, together with an institution, various or none at all, it allows us to have a general view of both the type of innovation, the financing obtained or simply the amount or variety of that knowledge.

\section{METHODOLOGY}

In order to carry out the studies, the "Repository of EIGood Practices" is considered, which contains the knowledge management model presented in this study (CSORA) (Fidalgo and Ponce, 2011). This repository is the result of an R\&D project financed by the Ministry of Education, Culture and Sport of the Government of Spain (Fidalgo et al., 2013). Two types of studies are presented: a qualitative analysis, by means of the LibQual survey, and a quantitative analysis, by means of analysing users' profiles and the ratio of ontologies/good practice in the proposed system.

- LibQual survey. It is applied to measure the quality of the "Repository of EI Good Practices" (Fidalgo et al. 2013), in a global way and for the different professional profiles.

- User profile. The profile of users that use the repository is analysed. The profile is made up of the variables: country and work centre.

- Ontologies/good practice. The ratio of ontologies, for the same category, with respect to the characteristics of the EI good practice that are associated with it, is studied. This analysis will be carried out in order to know the common points in different types of educational innovation.

\subsection{Qualitative study}

The LibQual survey, developed by the Association of Research Libraries, is an internationally validated standard and whose statistical analysis confirms the universality of the measured concepts (LibQual, 2014). This tool detects the quality of services based on the perception of users. It is formed of 22 questions, with a Likert scale (1 to 9), distributed in three dimensions: affective value of the service, the library as a place and information control. In this study, the information control has been chosen as a measure of the flows, usefulness and ease to locate the knowledge. The survey is profiled in three levels for each dimension: 
- Minimum required level (MV). With a level lower than MV the existence of the service is not consider.

- Observed Level (OV). The level that the user detects and perceives from the repository.

- Desired level (DV). The level that the users would like for the service.

Based on the evaluation of these three levels, two measures are obtained: suitability of the service and superiority of it.

- The suitability of the service (A) is calculated from the observed value (VO) and the minimum value (MV), as $\mathrm{A}=\mathrm{OV}-\mathrm{MV}$. The negative value of A means that they do not comply with the users' expectations regarding service are not met and the more suitable will increase further.

- The superiority of the service (S) is the difference between the observed value (OV) and the desired value (DV) $\mathrm{S}=\mathrm{OV}-\mathrm{DV}$.

Therefore, the DM-SCORE value allows knowing the percentage that has been achieved for the desired level by the user. In other words, $\mathrm{DM}=(\mathrm{A} / \text { Area of tolerance })^{*} 100$, the Area of tolerance being $=$ average of the DV - average of the MV.

The search engine, associated to the Repository of EI Good Practices, was used with the participants in the MOOC "Applied Educational Innovation" (Fidalgo et al., 2014), carried out by the authors of this study. The idea was to provide them, in an optional way, a tool to help them to apply EI in their contexts. To do so, good practices were selected from four international conferences. From a total of 1,917 MOOC participants, 851 used the Repository and, from this group of participants, 764 completed the LibQual survey. A double comparison was carried out using the variables suitability of the service, superiority of the service and DMSCORE.

1. The objective of the first comparison was to know the users' perception of the repository, contrasting the result with international results.

2. The second comparison was used to contrast the users' perception according to their profile. In this way, we are aware of the pereeption of individuals belonging to different contexts, but which have specific needs deriving from their $\varnothing$ wn context.

\subsection{Quantitative study}

In this study, data is extracted from the "Repository of EI Good Practice" itself.

From 10th April 2014, the search engine was opened to the university community without any form of restriction. In June 2014 the search engine documented more than 1,400 registered users. Amongst the information required for the registration, the country and the name of the academic institution are included. The main objective of this first analysis is to validate if the participants come from different countries and universities. We will use these variables as an indicator of whether a sectorial service can be built with a global view and it can be useful for all universities (first research question).

Finally, the good practices included in the repository will be analysed, as well as where they derive from and the knowledge area. In this way, we will have a view of the variety of EI good practices. This analysis is necessary to know the extent of diversity of the origin of knowledge, which will be used as an indicator of the heterogeneity of the EI. Another variable to be analysed in the good practices, is their grouping with the ontologies used and to have a common view of the EI. The result will be the degree of heterogeneity associated to the same ontology. It leads to confirm the second research question. 
These variables are used to know the degree of common visibility; in other words, the conversion to sectorial knowledge of the individual practice produced in specific subjects. It is studied whether the knowledge can be organised, deriving from specific contexts and with the same classification. With this, individual knowledge concerning EI will be able to be turned into sectorial knowledge (third research question).

\section{RESULTS}

The results are grouped into the following areas of analysis: results from the Libqual survey (measurement of the perceived service quality), LibQual survey results according to the users' profile (professional activity, to identify the variety of university contexts), quantitative results of the repository usage, the origin of participants (country/university) and grouping of EI good practice by common ontologies (to measure individual/sectorial knowledge relationship).

\subsection{Qualitative analysis LibQual concerning the quality of the Repository}

This involves qualitative analysis of the questions selected for the dimension "Controlling the information" (Likert scale from 1 to 9). The questions are:

- Q1. Access to electronic resources is feasible from home or office.

- Q2. The repository website allows to find information by myself.

- Q3. The resources cover the needs of information that I have.

- Q4. The search engine is modern and provides the information that I need with easy access.

- Q5. The search engine is easy to use and allows me to find what I am looking for.

764 answers were obtained from a population of 851 registered users of the Repository of EI Good Practices.

In Table 5 the Minimum Value (MV), Observed Value (OV), Desired Value (DV), Suitability (A), Superiority (S), Area of Tølerance (AT) and.Percentage of Achievement (DM-SCORE) can be observed for each relative question (Q). In Figures, the average values of MV, OV and DV are indicated.

Table 5. Varyes for the questions concerning "Controlling the information"

\begin{tabular}{|c|l|l|l|l|l|l|l|}
\hline $\mathbf{Q}$ & MV & OV & DV & A & S & AT & DM-SCORE (\%) \\
\hline 1 & 7.05 & 7.26 & 7.77 & 0.21 & -0.51 & 0.72 & 29.10 \\
\hline 2 & 7.14 & 7.37 & 7.82 & 0.23 & -0.45 & 0.68 & 33.83 \\
\hline 3 & 6.75 & 6.83 & 7.56 & 0.08 & -0.73 & 0.81 & 10.10 \\
\hline 4 & 7.16 & 7.25 & 7.80 & 0.09 & -0.56 & 0.65 & 13.55 \\
\hline 5 & 7.29 & 7.41 & 7.88 & 0.12 & -0.47 & 0.59 & 20.50 \\
\hline Average & $\mathbf{7 . 0 8}$ & $\mathbf{7 . 2 2}$ & $\mathbf{7 . 7 6}$ & $\mathbf{1 . 1 4}$ & $\mathbf{- 0 . 5 4}$ & $\mathbf{0 . 6 9}$ & $\mathbf{2 1 . 4}$ \\
\hline
\end{tabular}




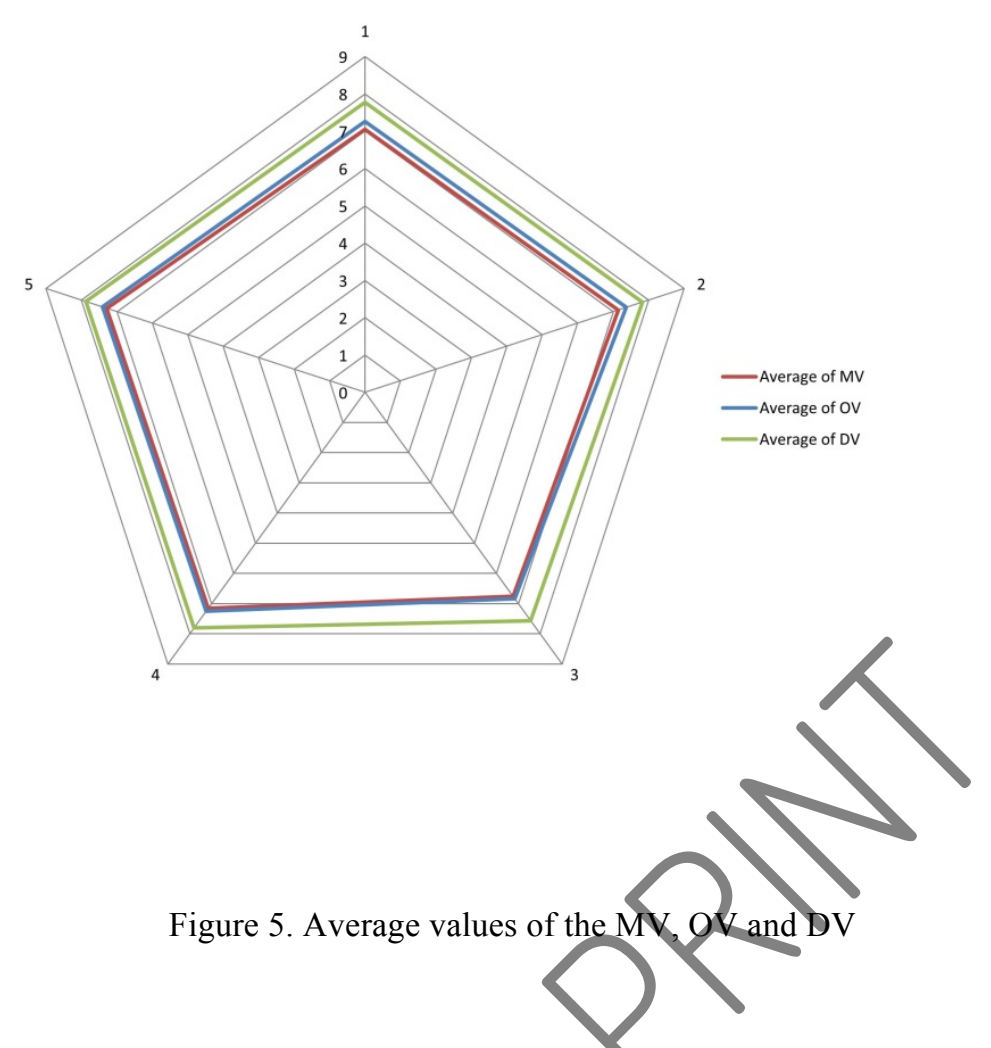

\subsection{Qualitative analysis LibQual of the quality of the Repository, according to the professional user's profile}

The results of the survey, depending on the professional profile of the users are now presented. These were classified by the following profile:

- Students. 407 individuals, 53\% of the sample (see Table 6).

- Teachers. 253 individuals $33 \%$ of the sample (see Table 7).

- Others (professionals interested in the EI and external to the academic environment) 104 individuals, $14 \%$ of thro sample (see Table 8 ).

Table 6. LibQual values for the "Student" profile

\begin{tabular}{|c|c|c|c|c|c|c|c|}
\hline Q & MV & OV & DV & A & S & AT & DM-SCORE (\%) \\
\hline 1 & 6.87 & 6.98 & 8.56 & 0.11 & -1.58 & 1.69 & 6.54 \\
\hline 2 & 6.94 & 7.14 & 7.66 & 0.16 & -0.53 & 0.73 & 22.28 \\
\hline 3 & 6.70 & 6.76 & 7.41 & 0.06 & -0.65 & 0.70 & 7.87 \\
\hline 4 & 7.11 & 7.19 & 7.68 & 0.08 & -0.49 & 0.57 & 14.48 \\
\hline 5 & 7.19 & 7.32 & 7.72 & 0.14 & -0.40 & 0.53 & 25.93 \\
\hline Average & $\mathbf{6 . 9 6}$ & $\mathbf{7 . 0 8}$ & $\mathbf{7 . 8 1}$ & $\mathbf{0 . 1 1}$ & $\mathbf{- 0 . 7 3}$ & $\mathbf{0 . 8 5}$ & $\mathbf{1 5 . 4 2}$ \\
\hline
\end{tabular}

Table 7. LibQual values for the "Teacher" profile

\begin{tabular}{|c|c|c|c|c|c|c|c|}
\hline $\mathbf{Q}$ & MV & OV & DV & A & S & AT & DM-SCORE (\%) \\
\hline 1 & 7.12 & 7.33 & 7.88 & 0.22 & -0.55 & 0.77 & 28.21 \\
\hline 2 & 7.27 & 7.51 & 7.95 & 0.24 & -0.44 & 0.68 & 35.74 \\
\hline 3 & 6.79 & 6.87 & 7.69 & 0.08 & -0.82 & 0.89 & 8.54 \\
\hline 4 & 7.22 & 7.39 & 7.90 & 0.17 & -0.51 & 0.68 & 24.82 \\
\hline 5 & 7.39 & 7.58 & 8.02 & 0.19 & -0.44 & 0.63 & 30.62 \\
\hline
\end{tabular}




\begin{tabular}{|l|l|l|l|l|l|l|l|}
\hline Average & 7.16 & 7.34 & 7.89 & 0.18 & -0.55 & 0.73 & 25.59 \\
\hline
\end{tabular}

Table 8. LibQual values for the "Other" profile

\begin{tabular}{|c|c|c|c|c|c|c|c|}
\hline Q & MV & OV & DV & A & S & AT & DM-SCORE (\%) \\
\hline 1 & 7.24 & 7.47 & 7.70 & 0.23 & -0.23 & 0.46 & 50.00 \\
\hline 2 & 7.13 & 7.46 & 7.70 & 0.33 & -0.24 & 0.57 & 57.63 \\
\hline 3 & 6.71 & 6.88 & 7.47 & 0.16 & -0.60 & 0.76 & 21.52 \\
\hline 4 & 7.06 & 7.16 & 7.73 & 0.11 & -0.57 & 0.67 & 15.71 \\
\hline 5 & 7.13 & 7.32 & 7.68 & 0.18 & -0.37 & 0.55 & 33.33 \\
\hline Average & $\mathbf{7 . 0 6}$ & $\mathbf{7 . 2 6}$ & $\mathbf{7 . 6 6}$ & $\mathbf{0 . 2 0}$ & $\mathbf{- 0 . 4 0}$ & $\mathbf{0 . 6 0}$ & $\mathbf{3 5 . 6 4}$ \\
\hline
\end{tabular}

\subsection{Quantitative analysis of the use of the repository according to users' affiliation}

The information obtained from the registration system of the repository itself. In Table 9, some of the characteristics of the participants are shown: Country (country where they work), Total (number of individuals registered per country) and University (number of universities registered for the country). It should be highlighted that not all of the individuals registered in the good practice repository work at universities.

Table 9. Affiliation of the participants in the Repository

\begin{tabular}{|c|c|c|}
\hline COUNTR & Total & Universities \\
\hline Argenti & 62 & 22 \\
\hline Boli & 9 & 4 \\
\hline Brazk & 27 & 10 \\
\hline chite & 29 & 6 \\
\hline Cotumbia & 72 & 20 \\
\hline Costa Rica & 3 & 2 \\
\hline Cuba & 4 & 2 \\
\hline Ecuador & 24 & 8 \\
\hline EI Salvador & 8 & 1 \\
\hline Spain & 654 & 52 \\
\hline United States of America & 1 & 1 \\
\hline The Philippines & 1 & 1 \\
\hline Guatemala & 9 & 5 \\
\hline Honduras & 7 & 2 \\
\hline Ireland & 1 & 0 \\
\hline Italy & 7 & 1 \\
\hline Japan & 2 & 2 \\
\hline Mexico & 149 & 26 \\
\hline Nicaragua & 6 & 3 \\
\hline Panama & 7 & 3 \\
\hline Paraguay & 7 & 4 \\
\hline Peru & 58 & 9 \\
\hline Portugal & 3 & 1 \\
\hline
\end{tabular}




\begin{tabular}{|l|l|l|}
\hline Puerto Rico & 2 & 0 \\
\hline Czech Republic & 1 & 1 \\
\hline Dominican Republic & 10 & 2 \\
\hline Uruguay & 8 & 3 \\
\hline Venezuela & 48 & 10 \\
\hline Without origin & 188 & \\
\hline & & \\
\hline Total & $\mathbf{1 4 0 7}$ & $\mathbf{2 0 1}$ \\
\hline
\end{tabular}

\subsection{Quantitative analysis of the good practice included in the Repository}

The repository currently contains 425 forms of good practice related to EI. These good practices derive from 5 conferences: CINAIC 2011 - 120 good practices, CITEC 201- 14 good practices, XXCUIEET 201220 good practices, JIIE-UZ 2012- 104 good practice, CINAIC 2013 - 114 forms of good practice (Fidalgo et al., 2013).

The classification by knowledge areas has been established according to Spanish university regulations. The information presented refers to the last 228 good practices entered in the repository. In the first beta version the first good practices were not designated to the "Knowledge Area" category. The percentage of good practices, distributed by knowledge area, is as follows: Arts and Humanities $8.77 \%$, Science $15.35 \%$, Social Sciences and Law 35.09\%, Engineering and Architecture 29.39\%, Health Science 11.40\%. Similarly, for the last 228 good practices included in the sample, they show the distribution of EI good practice, in line with their specific typology:

- Development (7.71\%) The result of work that leads to the creation of a new methodology or new product. If the methodology or product exists on the market, then they should considerably improve the existing one.

- Study (29.10\%) Work to study the students of the involved subjects.

- Experience (40.81\%) Work in which technology and/or existing methodologies are applied in the context of one or several subjects. Examples: applying a social network, including teamwork.

- Innovation (7.21\% - Work that involves innovation with respect to existing studies. The innovation should be of a general nature, which can be applied to any teaching area, as well as being feasible and with measurable results for improvement.

- Research (15.17\%) Work that involves research in any field related to EI. The research should be of a global nature (both in the field of work and in the size of the sample) and the results should produce new knowledge, applicable to the whole university community.

Lastly, the ontologies/good practice ratio is studied. In other words, Table 10 shows an example of common visibility of practice that, nevertheless, has a very different origin. The variables of the Table 10 are: Label-name of the ontology, Good practice- number practices associated to that ontology, Institutionsuniversities different to the corresponding ones with the practices associated with that ontology Area of knowledge- different scientific fields corresponding to the good practices associated with that ontology and Degrees- different qualifications related with the practices associated with that specific ontology. Next, the ontologies associated with the "Learning" category are analysed.

Table 10. Good practice in the Learning category

\section{LABEL}


Fidalgo-Blanco, Á., Sein-Echaluce, M. L., \& García-Peñalvo, F. J. (2014). Knowledge Spirals in Higher Education Teaching Innovation. International Journal of Knowledge Management, 10(4), 16-37. doi: 10.4018/ijkm.2014100102

\begin{tabular}{|l|c|c|c|c|}
\hline Master class & 3 & 3 & 3 & 3 \\
\hline $\begin{array}{l}\text { Collaboration of } \\
\text { external professionals } \\
\text { with teaching }\end{array}$ & 9 & 3 & 3 & 4 \\
\hline Laboratory classes & 24 & 11 & 5 & 9 \\
\hline Special practice & 16 & 7 & 3 & 4 \\
\hline $\begin{array}{l}\text { External curricular } \\
\text { practice }\end{array}$ & 7 & 7 & 4 & 13 \\
\hline Evaluation tests & 18 & 9 & 2 & 10 \\
\hline $\begin{array}{l}\text { Solving problems and } \\
\text { case studies }\end{array}$ & 18 & 2 & 3 & 11 \\
\hline Teaching studies & 4 & 9 & 4 & 5 \\
\hline Tutoring and mentoring & 25 & 7 & 4 & 4 \\
\hline $\begin{array}{l}\text { General dynamics of the } \\
\text { subject }\end{array}$ & 13 & & 4 & \\
\hline
\end{tabular}

\section{DISCUSSION OF THE RESULTS}

The main objective of this study is to show a way of turning individual knowledge about EI experiences into sectorial knowledge. Individual knowledge arises in the context of subjects and also develops, applies and dies (sometimes) in the subject itself. Therefore knowledge is very heterogeneous, without it having been designed to export it outside of the subject and to solve some very specific needs. In this situation it is difficult to give an overview of all these experiences (Huber, 2001). The repositories demand a great effort in order to find, interpret and apply knowledge (Boh, 2014), with such a high cost that it can be unusable (Fidalgo and Ponce, 2011). On the other hand, universities, although working with knowledge, do not normally promote a cooperative culture between teaching staff, nor students. This means that the creation of sectorial knowledge is even more difficult. A model, developed on the integration of Nonaka's knowledge spirals (Nonaka, 1991), identifies the processes so that there is interaction and conversion between individual and organisational knowtedge. It has been integrated with ontologies as a means of classifying the diversity of individual experiences. A two-layer system has been used: a physical layer and a conceptual layer to allow different people to meet their needs, regardless of the physical organisation of knowledge. The CSORA method includes the integration of previous models by means of a knowledge management product that incorporates functionality to convert individual knowledge into sectorial knowledge.

The analysis of the results of the LibQual survey confirms that the repository users are very demanding, because the difference between the minimum service and the desired level is never more than 1 point (of 9). This contrasts with other studies where the differences between the minimum value and the maximum are normally between 2 and 3 points as Ramos and Quintana (2011) show in a comparison between countries. Even more than 3 points in case studies of library repositories, such as Rodriguez and Galán (2013).

The observed value (OV) has an average of 7.22 points out of 9 . A study exists that is undertaken by a work group of the third Rebiun line and Quality of Rectors of Spanish Universities (CRUE) in which 5 Spanish university libraries participate and two Latin American ones (Mexico and Argentina). This study was undertaken in the university context (Herrera-Viedma et al., 2009) and, as far as the same questions are concerned, the average of the observed value is 6.3 , almost one point less than in the example presented here. 
Therefore, the results show that the users have a high level in terms of the use of repositories and they consider that the system meets their expectations of both the usefulness of the obtained information and its ease of use. This gives an indicator that answers the first and second research questions: is it possible to build sectorial knowledge based on individual experiences that are specific and not prepared to be used outside of the context in which they were produced? This contrasts with the conclusions obtained in other studies (Boh, 2014) and other recommendations for the convenience of the homogeneity of the knowledge to be managed (Whitworth, 2012). It also contrasts with the results regarding the high cognitive cost used in the search for information and its subsequent interpretation.

The qualitative results, carried out by different types of users, also produce the same indicator, validating the view obtained in this research. It should be remembered that the managed knowledge has been done by the teaching staff and for the teaching staff. Therefore, the most important profile to be taken into account is that of the teaching staff. In this sense, if we compare the results with those obtained in the study of CRUE, fewer differences are observed. It can be observed that students are more critical and professionals interested in EI are less critical, however outside of academic contexts.

Up to this point it is shown that qualitative data have measured the perception of users of the system. Similarly, the quantitative data also point toward the possibility and feasibility of carrying out a single repository that integrates different views and profiles.

The fact that there are repository users from 28 countries and 201 different universities proves that a common view has been achieved for the good practices deriving from just 5 countries and in very different contexts. This indicator allows confirming the sectorial nature of the repository that supports the main idea of this paper. In other words, it is possible to build sectorial knowledge based on specific, individual experiences and it can be achieved by means of a single and centralised repository.

The information of the good practices, included in the repository, has also been analysed. The different knowledge areas that define the good practices and the different views of their content (type of good practice) show that the content is very varied, and it is not prepared to be transferred to other sector because it is framed in specific contexts. Jherefore data on ontologies (Table 10), show that, very diverse practices are grouped together with a common view, although they have not compatibility, neither in knowledge area nor in university, and not even in the qualification or degree.

On the other hand, the heterogeneity of the knowledge stored in the repository, the ease of the search and the common visibility of the content, are some of the causes why students, non-university teaching staff and professionals interested in education and learning are registered in the repository. Subsequently, nonuniversity educational centres, ministries, associations and freelancers use it. Despite this data not having been counted in the quantitative results, they have been taken into consideration for the qualitative results.

\section{CONCLUSIONS}

This study provides data to address the development of sectorial repositories. It allows developments cheaper and less maintenance because it is easier and cheaper to maintain a single repository than various ones. It also makes available new information about the relationship between individual knowledge, valid in a local context (e.g. a subject) and sectorial knowledge, valid in a global context (e.g. all universities). Thus, this study provides a common view of knowledge, not just in one organisation but also in a set of them.

Likewise, the hegemony of organisations to convert individual knowledge into organisational knowledge is broken. This work shows that sectorial activities (such as conferences) make possible to apply the 
principles of the knowledge creation by the organisations but with a much broader view (e.g. a conference can organise knowledge of a sector facing a concrete university which organises its particular knowledge).

Therefore, this work can be used by conferences of any sector and typology, as well as organisations (universities, management or government entities) with creative force, where individual experiences of different format and contexts are produced.

Unlike traditional repositories, ontologies proposed in this paper allow to manage the knowledge generated in the EI good practices, regardless of the quantity and variety of them. Moreover, the dynamic design of ontologies presented here, allows adapting the indicators used to characterize a good practice, based on new methodological and technological advances. This ensures its sustainability over time.

The integration of best practices in no higher education is envisaged for future works, expanding the scope of the sector. As well as the inclusion of social web features such as adding polling, feedback, comments, etc.

\section{ACKNOWLEDGEMENTS}

We would like to thank the Spanish Ministry of Education, Culture and Sport the funding of the project EA2011-0035, the Government of Aragon, the European Social Fund and the Ministry of Education of the Region of Castilla-León for their support. Finally, the authors would like to express their gratitude to the research groups (LITI, http://www.liti.es; GIDTIC, http://gidtic.com and GRIAL, http://grial.usal.es).

\section{REFERENCES}

Alavi, M., and Leidner, D. E. (2001). Reviey: Knowledge management and knowledge management systems: Conceptual foundations and researeh issues, MIS Quarterly, 25(1), pp. 107-136.

Al-Husseini, S., and Elbeltagi, I. (2015). Knowledge Sharing Practices as a Basis of Product Innovation: A Case of Higher Education in Iraq, International Journal of Social Science and Humanity, 5(2), pp. 182-185.

Bartol, K., and Srivastava, A. (2002). Encouraging knowledge sharing: The role of organizational reward systems, Journal of Leadership and Organizational Studies, 9(1), pp. 64-76.

Boh, W. F. (2014). Knowledge Sharing in Communities of Practice: Examining Usefulness of Knowledge from Discussion Forums versus Repositories, The DATA BASE for Advances in Information Systems, 45(2), pp. 8-31.

Child, J. (1972). Organisation structure, environment and performance: the role of strategic choice, Sociology, 6(1), pp. 1-22.

Cochran-Smith, M., and Lytle, S. L. (1999). Relationships of knowledge and practice: teacher learning in communities. In A. Iran-Nejad, and C. D. Pearson (Eds.), Review research in education: Vol. 24. American Educational Research Association, Washington, DC.

Correa da Silva, F. S., Vasconcelos, W. W., Robertson, D. S., Brilhante, V., de Melo, A. C. V., Finger, M., and Agustí, J. (2002). On the insufficiency of ontologies: problems in knowledge sharing and alternative solutions, Knowledge-Based Systems, 15, pp. 147-167.

Damodaran, L., and Olphert, W. (2000). Barriers and facilitators to the use of knowledge management systems, Behaviour and Information Technology, 19(6), pp. 405-413.

Davenport, T. H., and Prusak, L. (1998). Working knowledge: How organizations manage what they know, MA: Harvard Business School Press, Boston. 
Davila, T., Epstein, M. J., and Shelton, R. (2006). Making Innovation Work: How to Manage it, Measure it, and Profit from it. Pearson Education, Upper Saddle River.

Fidalgo Blanco, Á., García-Peñalvo, F. J., \& Sein-Echaluce Lacleta, M. L. (2014). MOOC Innovación Educativa Aplicada. Retrieved January 16th, 2015, from https://www.miriadax.net/web/innovacioneducativa-aplicada.

Fidalgo, A., and Ponce, J. (2011). Método CSORA: La búsqueda de conocimiento, Arbor, 187(No. Extra 3), pp. 51-66.

Fidalgo Blanco, Á., Sein-Echaluce Lacleta, M. L., Lerís, D., and García-Peñalvo, F. J. (2013). Sistema de Gestión de Conocimiento para la aplicación de experiencias de innovación educativa en la formación. In Á. Fidalgo Blanco \& M. L. Sein-Echaluce Lacleta (Eds.), Actas del II Congreso Internacional sobre Aprendizaje, Innovación y Competitividad, CINAIC 2013 (pp. 750-755). Madrid, Spain: Fundación General de la Universidad Politécnica de Madrid.

García-Peñalvo, F. J. (2011). La Universidad de la próxima década: La Universidad Digital. In C. SuárezGuerrero \& F. J. García-Peñalvo (Eds.), Universidad y Desarrollo Social de la Web (pp. 181-197). Washington DC, USA: Editandum.

García-Peñalvo, F. J. (2015). Percepciones estratégicas de la Innovación Educativa. Retrieved February 2nd, 2015, from http://gredos.usal.es/jspui/handle/10366/125196.

García-Peñalvo, F. J., Colomo-Palacios, R., García, J., and Therốn, R. (2012). Towards an ontology modeling tool. A validation in software engineering scenarios. Expert Systems with Applications, 39(13), 11468-11478. doi: http://dx.doi.org/10.1016/j.eswa.2012.04.009.

Gray, P. H., and Durcikova, A. (2005). The Role of Knowledge Repositories in Technical Support Environments: Speed Versus Learning in User Performance, Journal of Management Information Systems, 22(3), pp. 159-190.

Gray, P. H., and Meister, D. B. (2004). Knowledge sourcing effectiveness, Management Science, 50(6), pp. 821-834.

Gunn, C. (2010). Sustainability factors for e-learning initiatives, ALT-J: Research in Learning Technology, 18(2), pp. 89-103.

Hansen, M. T. (2002). Knowłedge networks: Explaining effective knowledge sharing in multiunit companies, Organization Science, 13(3), pp. 232-248.

Hansen, M. T., and Haas, M.OR. (2001). Competing for attention in knowledge markets: Electronic document dissemination in a management consulting company, Administrative Science Quarterly, 46(1), pp. 1-28.

Herrera-Viedma, E., López-Gijón J. and Ávila, B. (2009). Satisfacción de usuarios y calidad. El modelo LibQual y su aplicación en bibliotecas españolas e iberoamericanas. Estudio sobre el Benchmarking. Grupo de Trabajo de la Línea 3 Rebiun y Calidad.

Hinds, P. J., Patterson, M., and Pfeffer, J. (2001). Bothered by abstraction: The effect of expertise on knowledge transfer and subsequent novice performance, Journal of Applied Psychology, 86, pp. $1232-1243$.

Huang, M.-H., Wang, E. T. G., and Seidmann, A. (2007). Price Mechanism for Knowledge Transfer: An Integrative Theory, Journal of Management Information Systems, 24(3), pp. 79-108.

Huber, G. P. (2001). Transfer of knowledge in knowledge management systems: Unexplored issues and suggested studies, European Journal of Information Systems, 10(2), pp. 72-79.

Kao, C.-P., and Tsai, C.-C. (2009). Teachers' attitudes toward web-based professional development, with relation to internet self-efficacy and beliefs about web-based learning, Computers and Education, 53(1), pp. 66-73. 
Fidalgo-Blanco, Á., Sein-Echaluce, M. L., \& García-Peñalvo, F. J. (2014). Knowledge Spirals in Higher Education Teaching Innovation. International Journal of Knowledge Management, 10(4), 16-37. doi: 10.4018/ijkm.2014100102

Koulikov, M. (2011). Emerging Problems in Knowledge Sharing and the Three New Ethics of Knowledge Transfer, Knowledge Management \& E-Learning: An International Journal, 3(2), pp. 237-250.

LibQual+ (2014). Available at: https://www.libqual.org/home (accessed 10 July 2014)

Liu, P., Raahemi, B., and Benyoucef, M. (2011). Knowledge sharing in dynamic virtual enterprises: A socio-technological perspective", Knowledge-Based Systems, 24, pp. 427-443.

Ma, M., and Agarwal, R. (2007). Through a Glass Darkly: Information Technology Design, Identity Verification, and Knowledge Contribution in Online Communities, Information Systems Research, 18(1), pp. 42-67.

Markus, M. L. (2001). Toward a theory of knowledge reuse: Types of knowledge reuse situations and factors in reuse success, Journal of Management Information Systems, 18(1), pp. 57- 93.

McLaughlin, M. W. (2002). Sites and sources of teachers' learning, in C. Sugure, and C. Day (Eds.), Developing teachers and teaching practice: International research perspectives. London: Routledge.

Nonaka, I. (1991). The knowledge-creating company, Harv. Bus. Rev., 69(6), pp. 96-104.

Nonaka, I., and Takeuchi, H. (1995). The Knowledge-Creating Company. Oxford University Press, Oxford.

Ramos, M. and Quintana, I. (2011). Modelo de Evaluación de Satisfacción de usuarios basado en LibQUAL. III Jornada de Buenas Prácticas del Consorcio Madroño. Available at: http://earchivo.uc3m.es/handle/10016/10977?locale-attribute=en. (accessed 10 July 2014).

Rodríguez, R and Galám, B. (2013). Libqual+, una herramienta para evaluar los servicios de información en las bibliotecas médicas. Actas IV Jornada nacional Virtual de Cieneias de la Información.

Roffe, I. M. (1998). Conceptual problems of continuous quality improvement and innovation in higher education, Quality Assurance in Education, 6(2), pp. 74-82.

Sánchez, M. P., and Elena, S. (2006). Intellectual capital in universities: Improving transparency and internal management, J. Intellect, 7(4), pp. 529-548.

Schultze, U., and Vandenbosch, B. 1998. Information overload in a groupware environment: Now you see it, now you don't, Journal of Organizational Computing and Electronic Commerce, 8(2), pp. 127-148.

Sein-Echaluce, M. L., Lerís, D., Fidalgo Blanco, Á., and García-Peñalvo, F. J. (2013). Knowledge management system for applying educational innovative experiences. In F. J. García-Peñalvo (Ed.), Proceedings of the First International Conference on Technological Ecosystems for Enhancing Multiculturality (TEEM'13) Ap. 405-410). New York, USA: ACM. DOI: 10.1145/25365.

Sheng. W., and Noe, R. A. (2010). Knowledge sharing: A review and directions for future research, Human Resource Management Review, 20, pp. 115-131.

$\mathrm{Su}, \mathrm{C}$., and Contractor, N. (2011). A multidimensional network approach to studying team members' information seeking from human and digital knowledge sources in consulting firms, Journal of the American Society for Information Science and Technology, 62(7), pp. 1257-1275.

Tan, H.P., Plowman, D., and Hancock, P. (2007). Intellectual capital and financial returns of companies, $J$. Intellect, 8(1), pp. 76-95.

Tseng, F.-C., and Kuo, F.-Y. (2014). A study of social participation and knowledge sharing in the teachers' online professional community of practice, Computers \& Education, 72, pp. 37-47.

Van den Hooff, B., and De Ridder, J. A. (2004). Knowledge Sharing in Context: The Influence of Organizational Commitment, Communication Climate and CMC Use on Knowledge Sharing, Journal of Knowledge Management, 8(6), pp. 117-130.

Veletsianos, G. (2010). A definition of emerging technologies for education, in G. Veletsianos (Ed.), Emerging technologies in distance education, AU Press, Edmonton, pp. 3-22.

Weatherly, L. A. (2003). The value of people: the challenges and opportunities of human capital measurement and reporting, Res. Q., 123, pp. 1-11. 
Whitworth, A. (2012). Invisible success: Problems with the grand technological innovation in higher education, Computers and Education, 59, pp. 145-155.

Wu, H.-Y., Chen, J.-K., and Chen, I.-S. (2011). Ways to promote valuable innovation: intellectual capital assessment for higher education system, Qual Quant. 46, pp. 1377-1391.

Yang, J. (2007). The Impact of Knowledge Sharing on Organizational Learning and Effectiveness. Journal of Knowledge Management, 11(2), pp. 83-90.

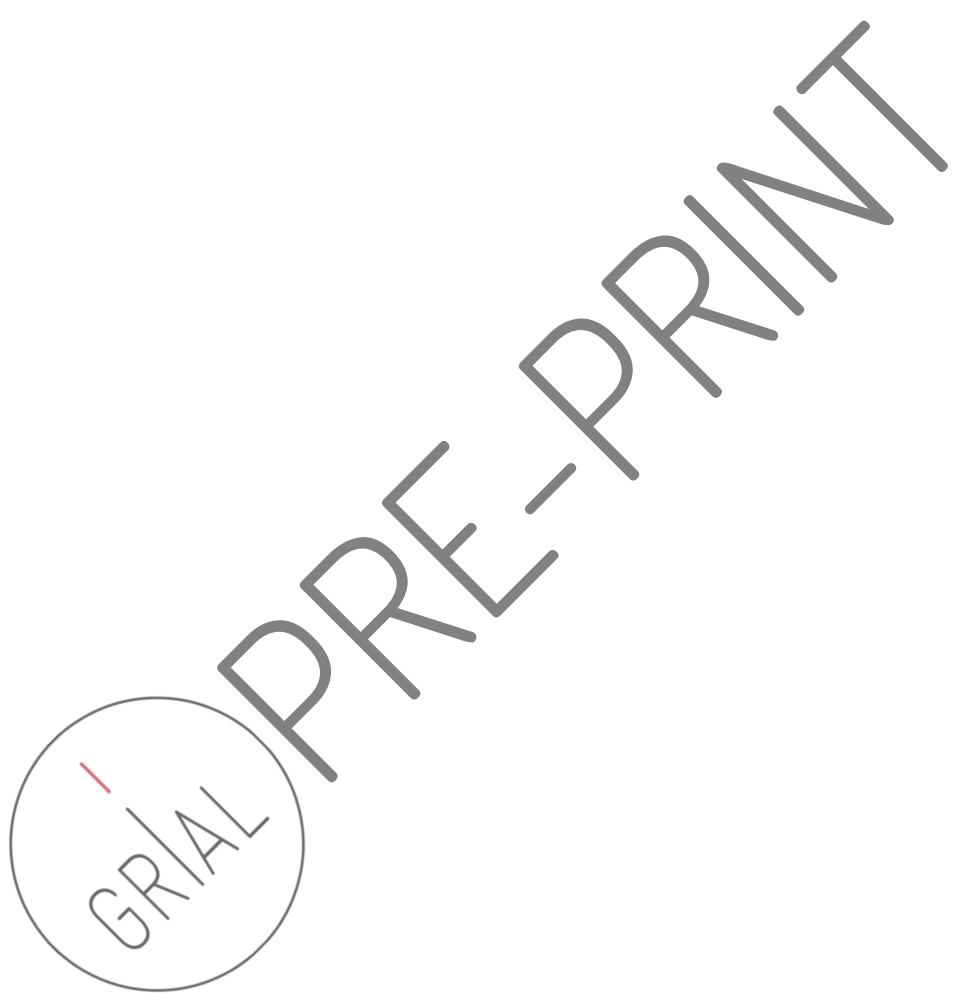

